\title{
Treatment of chromium(VI) waste by the non-living biomass of water hyacinth roots
}

\begin{abstract}
The potential of the biomass of non-living water hyacinth roots Eichhornia crassipes, as a biosorbent for $\mathrm{Cr}(\mathrm{VI})$ from synthetic solution and electroplating waste was investigated under batch conditions. Various factors affecting sorption of chromium were studied. They include effect of $\mathrm{pH}$, initial concentration, dosage, agitation rate, temperature and the presence of other anions. The optimum $\mathrm{pH}$ for the sorption was found to be 2.0 and sorption decreased rapidly as the $\mathrm{pH}$ of the solution was increased. Data obtained from sorption isotherms conformed to Langmuir sorption model which implied a monolayer coverage and the maximum sorption capacities of $\mathrm{Cr}(\mathrm{VI})$ were 8.93 and $8.92 \mathrm{mg} / \mathrm{g}$ for synthetic solution and electroplating waste respectively. A continuous flow study showed that water hyacinth root was effective in removing $\mathrm{Cr}(\mathrm{VI})$ from electroplating waste.
\end{abstract}

Keyword: Water hyacinth roots; Eichhornia crassipes; Biosorption; Chromium (VI); Electroplating waste 